УДК 621.1:532.59:532.66

О.Ю. Розіна, В.Б. Роганков

Одеська національна академія харчових технологій, вул. Канатна, 112, Одеса, 65039, Україна

\title{
ПРО ГЕНЕРАЦІЮ ТЕПЛОВОГО ПОТОКУ НА ПЕРЕРІЗІ КАПІЛЯРА ВНАСЛІДОК НЕОДНОРІДНОСТІ АКУСТИЧНОГО ПОЛЯ
}

На базі експериментальних досліджень звукокапілярного ефекту запропонована розрахункова модель формування теплового потоку через переріз капіляра, зануреного $в$ рідину, де створенні ультразвукові коливання. Кавітаційний проиес, збуджений під каналом капіляра, розглядається як послідовність фазових перетворень рідина-пара. Спрямований рух кавітаційних порожнин до каналу капіляра зумовлює розділення у просторі процесів, щчо ідуть з поглинанням тепла (під каналом капіляра), і процесів, щуо протікають з виділенням тепла (в каналі капіляра). Запропонована і програмно-реалізована розрахункова модель дозволяє оцінити густину теплового потоку, щзо формується на перерізі капіляру.

Ключові слова: Перенос тепла; Капіляр; Ультразвукова кавітація; Фазові перетворення

\section{О ГЕНЕРАЦИИ ТЕПЛОВОГО ПОТОКА НА СРЕЗЕ КАПИЛЛЯРА ОБУСЛОВЛЕННОЙ НЕОДНОРОДНОСТЬЮ АКУСТИЧЕСКОГО ПОЛЯ}

\begin{abstract}
На базе экспериментальных исследований звукокапиллярного эффекта предложена расчетная модель формирования теплового потока через сечение открытого капилляра, погруженного в жидкость, где созданы ультразвуковые колебания. Кавитационный прочесс, возбуждаемый под каналом капилляра, рассматривается как скачкообразная последовательность фазовых переходов жидкость-пар. Направленное перемещение кавитационных полостей в канал капилляра обусловливает пространственное разделение прочессов, протекающих с поглощением тепла (под каналом капилляра) и процессов, протекающих с выделением тепла (в канале капилляра). Предложенная и программнореализованная расчетная модель прочесса позволяет оченить плотность теплового потока, сформированного на срезе капилляра.
\end{abstract}

Ключевые слова: Перенос тепла; Капилляр; Ультразвуковая кавитация; Фазовые переходы

DOI: $10.15673 / 0453-8307.3 / 2015.42637$

This work is licensed under the Creative Commons Attribution International License (CC BY). http://creativecommons.org/licenses/by/4.0/

\section{I. ВСТУП}

Одним 3 сучасних напрямів розвитку теплоенергетики та холодильної техніки $\epsilon$ розробка термоакустичних холодильних пристроїв, у яких реалізований зворотний термоакустичний ефект. Його суть полягає у тому, що у газовому середовищі при створенні системи стоячих хвиль певної конфігурації фор-мується градієнт температур, зокрема формуються області, в яких температура знижена відносно рівноважної температури середовища. В літературі представлена достатня кількість публікацій, в яких надається теоретичне обгрунтування зворотного термоакустичного ефекту та обговорюються експериментальні дослідження на макетах пристроїв, описаних і задекларованих в патентах [1-10]. Не зупиняючись на деталях описаних пристроїв та отриманих результатів, звернемо увагу на те, що всі розробки базуються на хвильових процесах, реалізованих в однофазних інертних газах (чистих, або їх сумішах), які знаходяться під значним тиском до 10-15 Атм. У той же час відомо, що у звичайних холодильних установках компре-сійного або адсорбційного типів створення ефективних циклів для більш традиційних робочих тіл (води, перш за все) неможливе без організації фазових переходів у випарювачі та конденсаторі.

Метою цієї роботи є розробка узгодженої 3 експериментальними даними розрахункової моделі формування потоку тепла в неоднорідному акустичному полі внаслідок спеціально організованих періодичних фазових перетворень в рідині.

\section{ІІ. ЕКСПЕРИМЕНТАЛЬНЕ ПІДІРУНТЯ}

Одним 3 характерних процесів нелінійної акустики є кавітація. Це досить ефективний засіб суттєвого впливу на властивості рідини з метою стимулювання в ній тих чи інших фізико-хімічних процесів. Але перешкодою на шляху широкого використання кавітаційних технологій $\epsilon$, поперше, відсутність надійних методів локалізації та управління кавітаційним процесом; а по-друге, звичайне відношення до кавітації як до екзотичного, руйнівного по фізичній суті, процесу. 
В основу даної роботи покладені експериментальні дослідження звукокапілярного ефекту [11,12], а також концепція, згідно 3 якою акустична кавітація розглядається як ланцюг періодичних фазових перетворень в рідині, генерованих періодичним зниженням тиску у високоамплітудній ультразвуковій хвилі $[13,14]$.

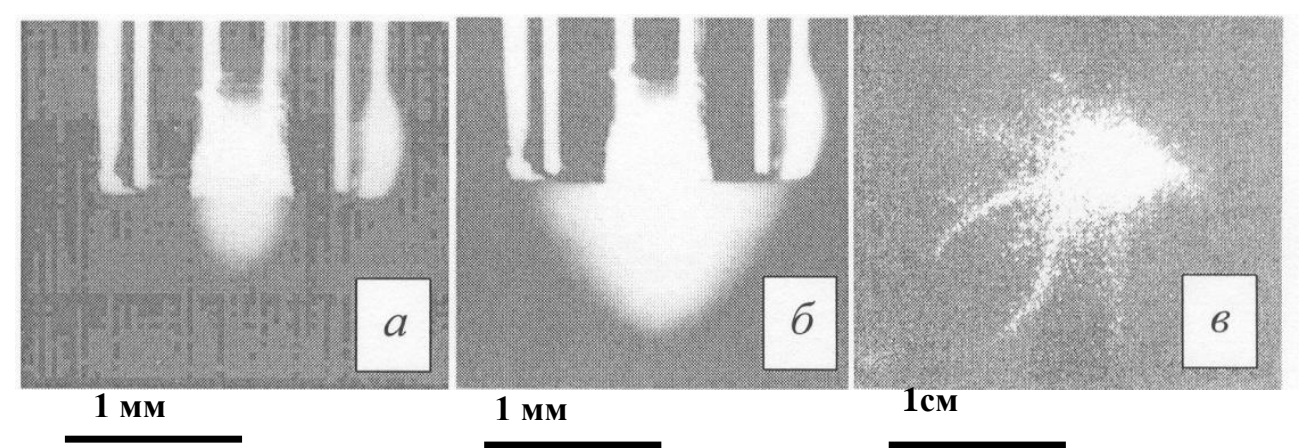

Рисунок 1 - Кавітаџійний проиес

на перерізі капіляру з внутрішнім діаметром $0,34 \cdot 10^{-3}$ м у дистильованій воді на відстані $12 \cdot 10^{-3}$ м від поверхні ультразвукового випромінювача, амплітуда звукового тиску $2 \cdot 10^{4}$ Па (a) і $3 \cdot 10^{4}$ Па (б); характерна картина кавітаційного процесу, що спонтанно виникає на поверхні ультразвукового випромінювача (в).

Суттєвими для даної роботи ми вважаємо такі відомі прояви звукокапілярного ефекту.

- Якщо капіляр розташований в рідині над ультразвуковим випромінювачем, то кавіта-ційний процес охоплює тільки обмежену область середовища, локалізовану строго під каналом капіляра (рис.1 $a$, б), на відміну від "розмитої" картини кавітації [15], збудженої у відсутності капіляра (рис.1 в).
- Кавітаційні порожнини, що складають кавітаційну хмару, не тільки пульсують відносно нерухомого центру, а спрямовано рухаються до нижнього (вхідного) перерізу каналу капіляра. На рис.2 показаний результат обробки кінограми, отриманої методом надшвидкісної з'йомки 3 частотою 160 тис. кадр/с на установці i за методикою, детально описаними в роботі [11].

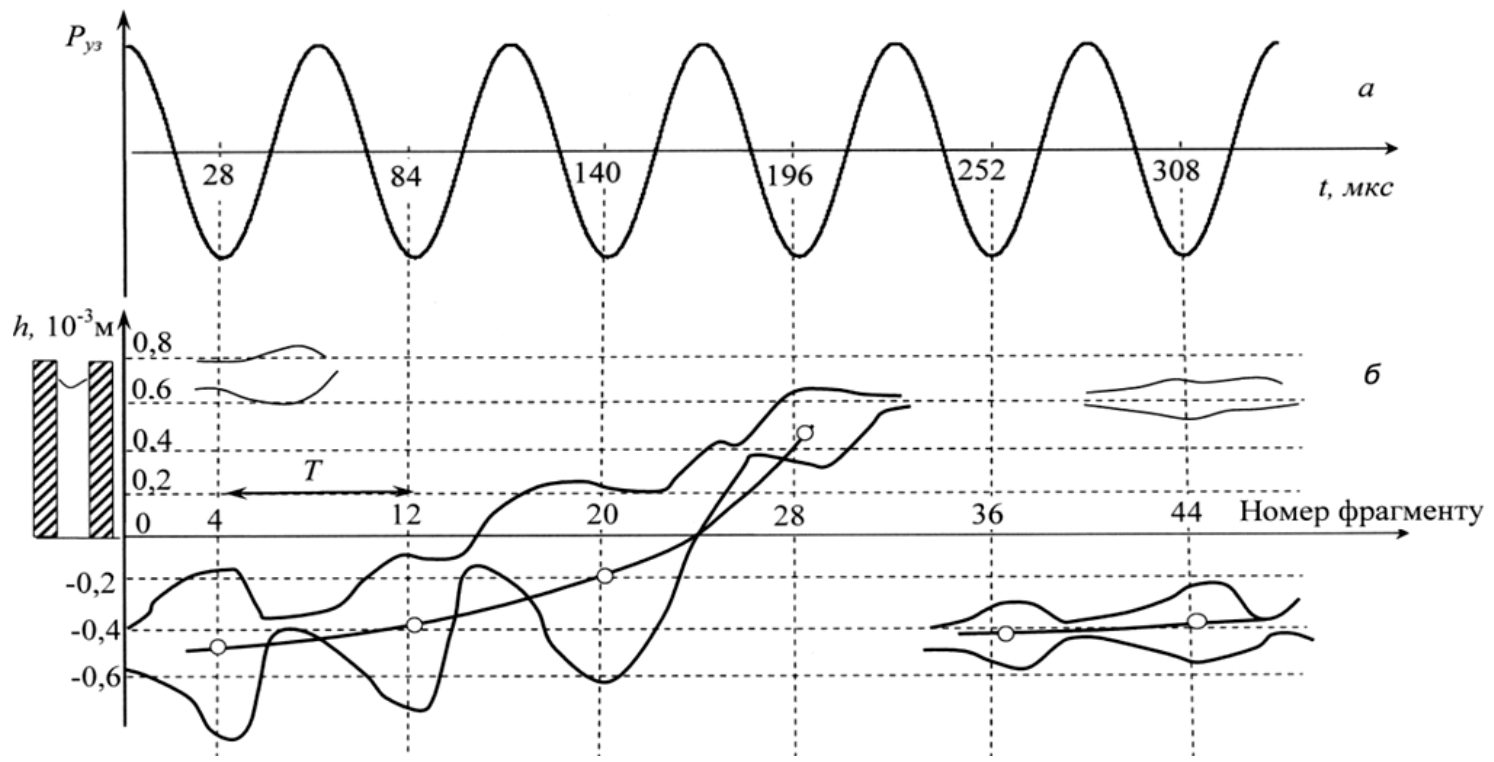

Рисунок 2 - Ультравуковий тиск під каналом капіляра (а) синзронізований з результатом обробки зображення кавітаційного процесу (б).

На 49 фрагментах кадра фотореєстратора представлено 6 періодів ультразвукових коливань. Криві позначають верхню та нижню границю області, заповненої кавітаційними порожнинами. Позначка (о) характеризує положення «центру тяжіння» кавітаційної хмари у фазі найбільшого розтягнення порожнин. 
- $\quad$ Збудження кавітації під каналом капіляра зумовлює локальний розігрів в зоні кавітації. На рис.3 a порівнюються графіки двох експериментальних залежностей: $\Delta T(h)$, перевищення локальної температури $T$ над середньою температурою $T_{o}$ рідини як функція від $n(h)$, що характеризує у відносних одиницях зміну концентрації порожнин у кавітаційному процесі, показаному на рис.3 б. Обидві криві мають характерні максимуми, суттєво зміщені один від одного [12].

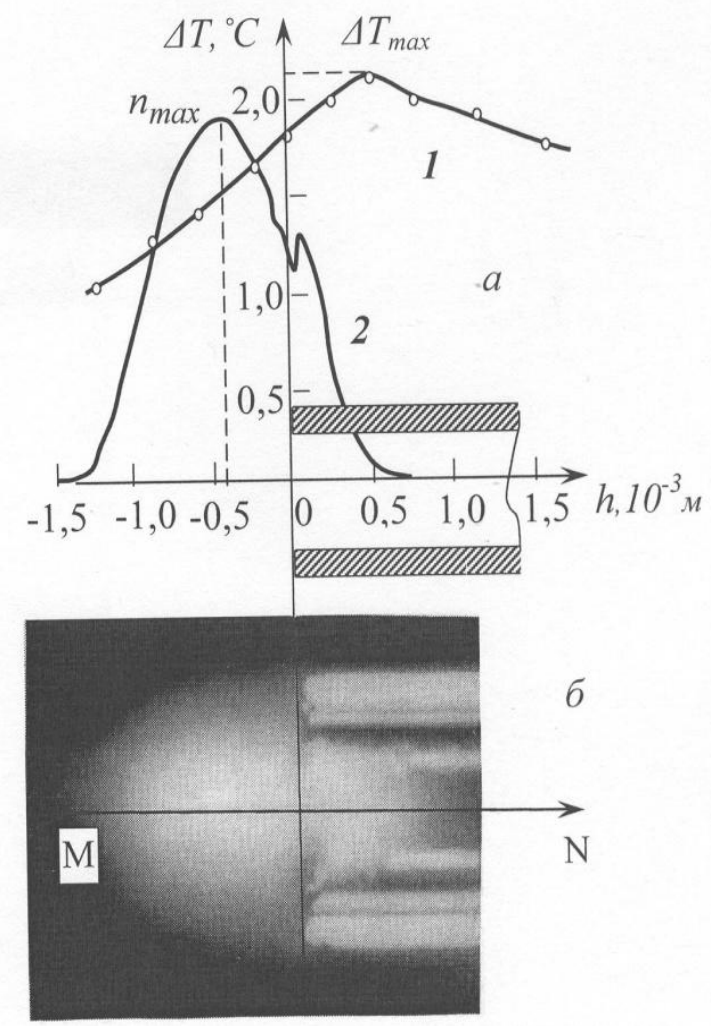

Рисунок 3. -Розподіл температури (1) та концентрації кавітаційних порожнин (2) уздовж осі капіляра $(a)$; кавітаційний процес на капілярі 3 внутрішнім діаметром $0,7 \cdot 10^{-3}$ м, для якого отримані криві 1 і 2 (б).

Аналізуючи ефекти, що могли б сприяти розігріву рідини в зоні кавітації, визначимо, що періодичне розширення та змикання порожнин у в'язкій рідині повинне супроводжуватись дисипацією, цей ефект міг би пояснити загальний розігрів кавітуючого середовища. Але зауважимо, що дисипація не може бути причиною зміщзення піку температурної кривої всередину каналу капіляра, де відбувається найшвидше згасання кавітаційного процесу. Для інтерпретації такого зміщення необхідно прийняти до уваги, на наш погляд, взаємодію теплових флуктуацій 3 дослідженням спрямованого руху кавітаційних порожнин до каналу капіляра, а також наявністю флуктуацій густини перед вхідним перерізом капіляра.

\section{III. ПРОСТА КОНЦЕПТУАЛЬНА МОДЕЛЬ ФОРМУ-ВАННЯ ТЕПЛОВОГО ПОТОКУ НА ПЕРЕРІЗІ КАПІЛЯРА}

Приведені зображення кавітаційного процесу на рис.1, $a$ та рис.3,б представляють собою осереднене розподілення кавітаційних порожнин за інтервал часу, що дорівнює часу експозиції (1/30 c). Це на декілька порядків перевищує один період ультразвукової хвилі. Опираючись безпосередньо на кінограми процесу, приведені роботі [11], а також використовуючи результати їх обробки, показані на рисунку 2, біля перерізу капіляра можна виділити три характерні області, показані на рисунку 4. В області I відбувається формування окремих кавітаційних порожнин. Вони поступально рухаються до каналу капіляра $\mathrm{i}$ в області II формується достатньо щільний конгломерат кавітаційних порожнин, тобто область II - це область їх максимальної концентрації і мінімальної густини рідини. Внаслідок дії звукокапілярного тиску цей конгломерат рухається в канал капіляра, тобто в область експоненціального зменшення ампліту-ди $P_{m}$. На шляху II - III відбувається змикання окремих кавітаційних порожнин. Внаслідок зменшення $P_{m}$ цей процес уповільнюється у порівнянні 3 процесом змикання під каналом капіляра, тим не менше на глибині порядку

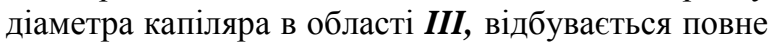
змикання кавітаційних порожнин i загасання кавітаційного процесу.

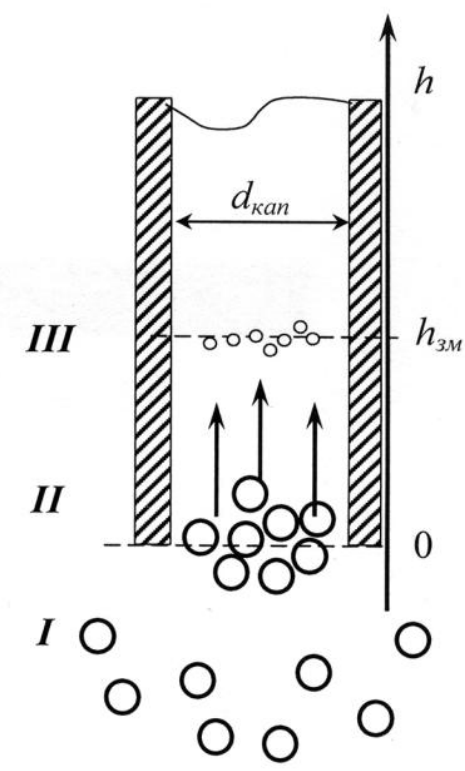

\section{Рисунок 4 - Схема розвитку кавітаційного прочесу на перерізі капіляра відношення $\left(h_{\text {зм }} / d_{\text {кап }}\right)$ порядку 1}

Якщо акцентувати увагу на тому, що на частоті порядку 20 кГц за час порядку $10^{-5} \mathrm{c}$ мікропорожнина збільшує свій об'єм на три порядки (ії діаметр зростає від $10^{-5} \mathrm{M}$ до $10^{-4} \mathrm{M}$ ), кавітація видається специфічним ефектом, для 
якого припустимим $є$ обговорювати механічні високочастотні пульсації вакуумних порожнин. Але, зростання i змикання порожнин, зареєстроване швидкісним фотореєстратором, свідчить також, що це є відносно повільний процес, у якому середня радіальна швидкість руху границі кавітаційної порожнини має порядок $(1 \div 2)$ м/с. Тому цілком прийнятним нам здається твердження, що зростання кавітаційної порожнини супроводжується фізично добре зрозумілим процесом - випаровуванням рідини 3 внутрішньої поверхні кожної порожнини. Цей процес в будь-яких масштабах потребує кількості тепла

$$
\Delta q=r(\bar{T}) \cdot \Delta m,
$$

де $r$ - питома теплота пароутворення при середній температурі рідини $\bar{T}, \Delta m$ - маса рідини, яка перетворилась на пару в процесі зростання порожнини. Зрозуміло, що на початку кавітаційного кипіння процес $є$ суттєво нестаціонарним, але проста модель, що запропонована нижче, ігнорує ці складнощі.

В капілярі в області II - III відбувається зворотний процес: змикання поверхні і конденсація пари на поверхні порожнини у стадії зменшення іiі об'єму, і цей процес супроводжується виділенням еквівалентного тепла, якщо вважати його термодинамічно-оборотним. Отже, періодичне формування кавітаційної хмари під перерізом капіляра i відбір тепла в цьому обсязі, а потім і його спрямований рух до каналу капіляра, де тепло частково віддається рідині, зумовлює розділення у просторі процесів, які відбуваються з поглинанням і виділенням тепла. Характерно, що тепло відбирається з локального об’єму $\boldsymbol{I}-\boldsymbol{I I}$ в області формування кавітаційної хмари, а «скидання» тепла відбувається у обмеженому просторі $\boldsymbol{I I}$ - III в каналі капіляра, до чого, звичайно, потрібно добавити роботу по утворенню зародків (бульбашок) газу в об'ємі $\boldsymbol{I}$ II , а також треба добавити врахування дисипації енергії, яка супроводжує процес згасання кавітації в об'ємі II - III. Однак, без цих ускладнень для густини потужності теплового потоку $j_{q}$, що перетинає переріз капіляра через одиницю площини його нормального перерізу $A_{\perp}$, маємо вираз

$$
j_{q}=\frac{1}{\Delta t \cdot A_{\perp}} \cdot r(\bar{T}) \cdot \Delta m \cdot N(\bar{R}, v),
$$

у якому $N-$ повна кількість порожнин, з середнім радіусом $\bar{R}$ при частоті звукового поля $v$, які перетинають протягом часу $\Delta t$ нормальний переріз каналу капіляра площею $A_{\perp}$. Як видно з виразу (2) , щоб визначити величину $j_{q}$, необхідно оцінити масу рідини $\Delta m$, яка перетворилась на пару в процесі зростання окремої порожнини. Кількість порожнин $N$, що за час $\Delta t$ увійшли до каналу капіляру, можна оцінити використовуючи результати експери-ментів, зокрема 3 кінофрагментів, отриманих за допомогою надшвидкісного фотореєстратора. Що стосується величини $\Delta m$, тобто кількості пари, що утворюється в процесі розтягнення порожнини, зазначимо, що не існує простих фізичних міркувань, чи є пара в порожнині насиченою весь час протягом її розширення.

У відповідності до прийнятих уявлень, інтенсивність процесу випаровування рідини визначається дифузією пари 3 поверхні рідини в газове середовище, причому у тонкому приповерхневому шарі пара $\epsilon$ насиченою. Для краплини рідини, яка знаходяться в газовому середовищі, випаровування відбувається у необмежений простір, i задача про швидкість випаровування 3 поверхні крапель має точне аналітичне розв'язання [16, c.471]. В нашому випадку випаровування рідини відбувається в обмежене середовище порожнини змінного радіусу, тобто процес випарування описує диференціальне рівняння 3 нестаціонарними граничними умовами. Щоб уникнути розв'язання складної математичної задачі, було розроблено алгоритм, який дозволяє 3 достатньою точністю визначити зміну густини пари у процесі розширення порожнини. Додатковою метою цього кроку було створення достатньо простої моделі формування потоку тепла, базуючись на експериментальних параметрах.

Суть методу пояснимо у відповідності до рисунку 5. Відбувається досить повільний процес безперервного розширення порожнини від радіусу $R_{\min }$ до $R_{\text {max }}$ який супроводжується безперервним випарування рідини в порожнину. Розіб'ємо його на послідовність дискретних процесів, у яких відбувається миттєве зростання радіусу порожнини на величину від $r_{i-1}$ до $r_{i}$, отже миттєво формується відповідний прошарок ненасичений парою. Далі протягом часу $\Delta t_{i}$ в нього випаровується кількість рідини $\Delta m_{i}$. На рисунку 5 $a$ штриховими лініями показана послідовність сферичних поверхонь, які відповідають ланцюгу дискретного покрокового зростання радіусу порожнини від значення $R_{\min }$ до $R_{\max }$. На момент часу, показаний на схемі, границя порожнини співпадає 3 поверхнею радіусу $r_{i}$, зовні якої знаходиться щільна рідина. На внутрішній поверхні цієї порожнини знаходиться тонкий прошарок насиченої пари. Сферична поверхня радіусу $r_{i-1}$ охоплює об'єм, заповнений парою, густина якої визначається випаруванням на попередній стадії розширення.

На рисунку 5 а нами виділена довільна область рідини, яка охоплює шар порожнини, обмежений радіусами $r_{i-1}$ та $r_{i}$. 


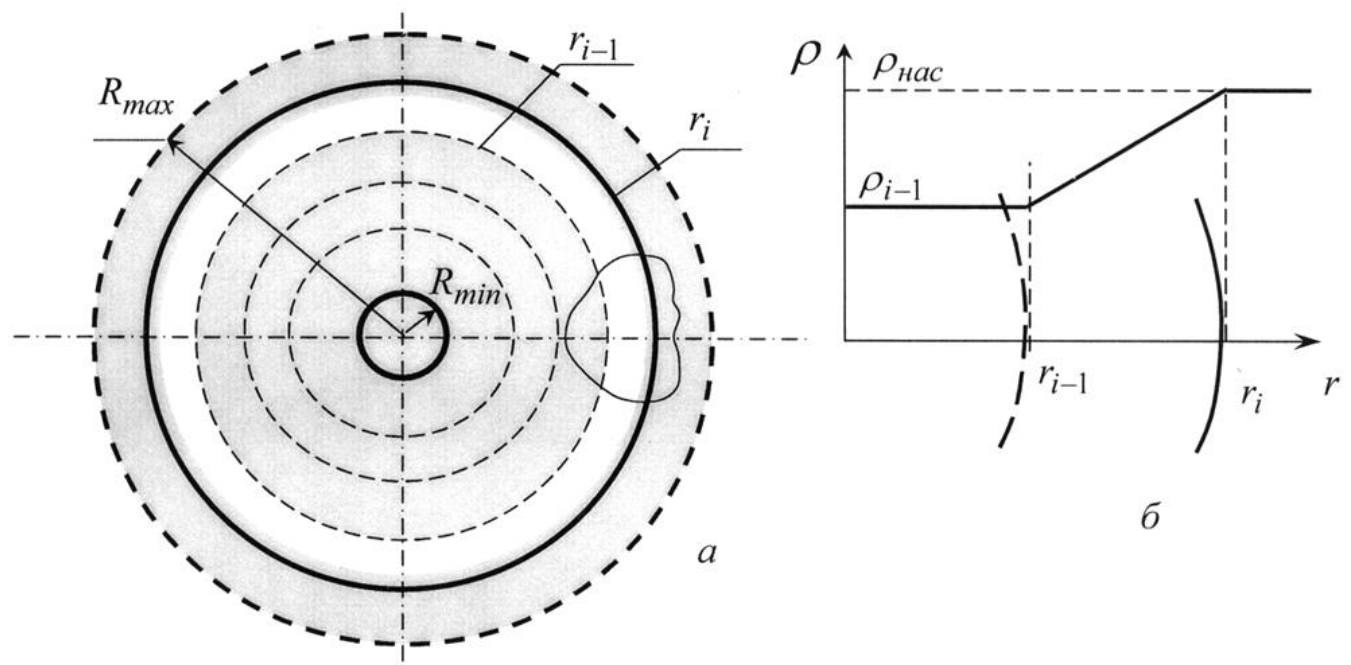

Рисунок 5 -Процес потарового зростання кавітаційної порожнини (а) та зміна густини пари у сформованому прошарку (б)

Мінімальний радіус $R_{\min }$, відповідає зародку кавітації, зростання порожнини до максимального радіусу $R_{\max }$ відбувається через послідовність радіусів $r_{i}$; між фазовими границями $r_{i}$ та $r_{i-1}$ формується прошарок, у який випаровується рідина.

Рисунок 5 б ілюструє схему зміни густини $\rho(r)$ i формування ii градієнту в модельованому таким чином шарі порожнини. Зазначимо, що $r_{i}$ відповідає радіусу порожнини у даний момент часу, тобто на цій поверхні пара $є$ насиченою $\rho_{\text {нас }}$. На поверхні 3 радіусом $r_{i-1}$ встановлюється значення густини $\rho_{i-1}$ яка $є$ результатом попередніх (i-1) процесів. У таких позначеннях рівняння Фіка, що описує процес дифузії пари протягом часу $\Delta t_{i}$ через сферичну поверхню площиною $A_{\perp}$, має вигляд

$$
\begin{array}{r}
\Delta m_{i}=D \cdot \frac{d \rho}{d r} \cdot A_{\perp} \cdot \Delta t_{i} \cong \\
\cong D \cdot \frac{\rho_{\mu a c}-\rho_{i-1}}{\Delta r_{i}} \cdot\left(4 \cdot \pi \cdot r_{i}^{2}\right) \cdot \Delta t_{i} .
\end{array}
$$

(У цьому виразі $D$ - коефіцієнт дифузії молекул рідини, що випаровується).

\section{IV. ПРОГРАМНА РЕАЛІЗАЦІЯ МОДЕЛІ I ОТРИМАНІ РЕЗУЛЬТАТИ}

Для реалізації описаного алгоритму було прийнято, що зростання радіусу порожнини відбувається протягом від'ємного напівперіоду коливань, тобто протягом часу $T / 2=1 /(2 \cdot v)$. Крім того, вважалось, що швидкість руху поверхні порожнини $є$ сталою величиною порядку $u_{r}=2 R_{\max } \cdot v$. Для розрахунків обирали 10 кроків зростання $i$-радіусів, тобто $R_{\max }=10 \cdot R_{\min }$, відповідно радіус $i$-тої фазової границі, зображеної на схемі (Рисунок 5 а) задається як $r_{i}=i \cdot R_{\max } / 10$.

Однією 3 переваг розробленого у роботі програмного забезпечення в середовищі Delphi $\epsilon$ можливість створювати багатовіконні модульні програми. Це дає змогу економними засобами ускладнювати програму, зокрема розширювати коло фізичних параметрів, що розраховуються, змінювати умови моделювання процесу. Розроблений інтерфейс передбачає можливість ручного вводу поточних даних, а саме радіусу кавітаційної порожнини у фазі максимального розширення $R_{\max }$, температури рідини $\bar{T}$, відповідної густини насиченої пари $\rho_{\text {нас }}$, коефіцієнта дифузії $D$, а також частоти ультразвукових коливань $v$. передбачені та реалізовані такі можливості:

(1) покрокове визначення кількості теплоти, що віднімається від рідини у процесі розширення;

(2) покрокове визначення кількості теплоти, що віддається в рідину у процесі змикання порожнини;

(3) визначення загальної теплоти, відібраної під перерізом капіляра в зоні $\boldsymbol{I}, \boldsymbol{I I}$ для процесу розширення однієї порожнини;

(4) визначення загальної теплоти, виділеної в каналі капіляра в зоні III для процесів стиснення одної порожнини;

(5) покрокове обчислення зниження температури тонкого шару навколишньої рідини у процесі розширення порожнини;

(6) покрокове зростання температури шарів навколишньої рідини у процесі стиснення порожнини;

(7) оцінка зменшення кінетичної енергії шарів рідини при змиканні порожнини, яка враховує дисипативні ефекти, зумовлені в'язкістю; як зазначалось вище, дисипація зі свого боку вносить вклад в розігрів рідини в зоні кавітації.

Крім того у програмі передбачена та реалізована варіація параметрів, таких як максимальний радіус кавітаційної порожнини, температура навколишньої рідини i частота ультразвукових коливань. Це дає змогу оцінити сумарний вклад порожнин, що утворюють кавітаційну хмару, враховуючи кількість 
порожнин $N(\bar{R}, v)$ в залежності від їх середнього радіусу та від частоти ультразвуку.

Основні отримані результати можна узагальнити таким чином. Варіація температур у широкому діапазоні від $5{ }^{\circ} \mathrm{C}$ до $80{ }^{\circ} \mathrm{C}$ показала, що для кожної частоти і радіусу порожнини існує гранична температура, для якої необхідн модифікувати модель. На частоті 18,4 кГц, наприклад, що відповідає базовим експериментам, для порожнини $R_{\max }=1 \cdot 10^{-4}$ м такою граничною температурою $€ \quad 60{ }^{\circ} \mathrm{C} \quad\left(\begin{array}{lllll}333 & \mathrm{~K}\end{array}\right)$. Критерієм переходу від основного способу розрахунку до модифікованого було обрано співвідношення між часом випаровування рідинии на $i$-тому кроці обчислень $\Delta t_{i}=1 /(20 \cdot v)$ та часом $\tau_{\text {нас }}$, необхідним для випарування рідини у сформований прошарок між $i$-тою та $(i$-1)-шою фазовими границями до стану насиченої пари.

При температурах вище $60^{\circ} \mathrm{C}$ час випаровування даному кожному етапі значно перевищує час випарування до стану насиче-ності $\Delta t_{i}<\tau_{\text {нас }}$, (тобто пара $\epsilon$ ненасиченою протягом усього росту порожнини). У цьому випадку реалізується основний алгоритм, у якому використовується вираз (3). При температурах, менших $60^{\circ} \mathrm{C}$, виконується протилежна нерівність, i значення $\Delta m_{i}$ визнача-ється вже за спрощеною процедурою, в чому полягає концепція запропонованої модифікації:

$$
\Delta m_{i}=\rho_{\text {нас }} \cdot 4 \cdot \pi\left(r_{i}^{2}-r_{i-1}^{2}\right) \cdot \Delta r_{i} .
$$

У Таблиці 1 представлені результати розрахунків теплоти $\Delta q_{i}$, виділеної кавітацій-ними порожнинами в рідину внаслідок конден-сації пари на кожному етапі змикання. Дані приведені для порожнини 3 максимальним радіусом $10^{-4} \mathrm{M}$, найбільш ймовірним у розвину-тому кавітаційному процесі на частоті 20 кГц. Це відповідає умовам проведення експери-ментів, описаних у роботі [12].

Таблиця 1. Кількість теплоти, виділена в рідині при зменшенні поточного радіусу порожнини від $r_{i+1}$ до $r_{i}$

\begin{tabular}{|c|c|c|c|c|c|c|c|c|c|c|}
\hline$i$ & 9 & 8 & 7 & 6 & 5 & 4 & 3 & 2 & 1 & Сумарний ефект \\
\hline $\begin{array}{c}T_{o} \\
\mathrm{~K}\end{array}$ & \multicolumn{9}{|c|}{$\begin{array}{c}\text { внаслідок конденсації } \Delta q_{i} \cdot 10^{9}, \text { Дж при різних температурах } \\
\text { навколишньої рідини }\end{array}$} & $Q=\Sigma\left(\Delta q_{i}\right)$ \\
\hline 288 & 32,9 & 26,3 & 20,5 & 15,4 & 11,1 & 7,40 & 4,49 & 2,31 & 0,85 & 121,3 \\
\hline 293 & 44,9 & 36,0 & 28,0 & 21,1 & 15,1 & 10,1 & 6,14 & 3,15 & 1,16 & 165,7 \\
\hline \multirow[t]{3}{*}{298} & 60,1 & 48,1 & 37,5 & 28,2 & 20,2 & 13,5 & 8,20 & 4,21 & 1,55 & 221,5 \\
\hline & \multicolumn{9}{|c|}{ внаслідок зменшення кінетичної енергії шару рідини $\Delta E_{i} \cdot 10^{9}$, Дж } & $\Delta E=\Sigma\left(\Delta E_{\mathrm{i}}\right)$ \\
\hline & & 1,53 & 1,36 & 1,191 & 1,021 & 0,850 & 0,681 & 0,510 & 0,340 & 7,483 \\
\hline & & & & & & 100 & $51_{10}=$ & & $\begin{array}{l}\text { нден } \\
\text { min }\end{array}$ & \\
\hline
\end{tabular}

Як видно 3 таблиці, на кожному етапі стиснення порожнини параметр $\Delta q_{i}$ приймає значення порядку $10^{-9}$ Дж. Для густини потоку теплоти через сферичну границю розділу, тобто для параметру $\Delta q_{i} /\left(\tau \cdot S_{i}\right)$, маємо значення порядку $10^{6} \mathrm{BT} / \mathrm{m}^{2}$. Цей результат узгоджується 3 результатами, отриманими в роботі $[17$, стор.89$92,190]$ з використанням більш склад-них рівнянь гідродинаміки та тепломасо-переносу, адаптованих до нестаціонарного кавітаційного процесу.

Для порівняння у таблиці представлене пошарове зменшення кінетичної енергії рідини $\Delta E_{i}$ при змиканні порожнини. Ця величина характеризує зменшення енергії, зумовлене в'язкими ефектами (гальмуванням рідини). Вона майже дорівнює кількості тепла, виділеного в області змикання внаслідок в'язкості рідини. У відповідності до позначень на рисунку 5 довільний шар рідини, що знаходить між $i$-тою та $(i+1)$-шою фазовими границями має кінетичну енергію

$$
E_{i} \cong \frac{m_{i}}{2}\left(u_{r}\right)^{2}
$$

При переході рідини у шар між $i$-тою та $(i-1)$-ю фазовими границями зменшується маса рухомої рідини і втрата кінетичної енергії становить

$$
\Delta E_{i} \cong\left(m_{i}-m_{i-1}\right) \cdot \frac{\left(u_{r}\right)^{2}}{2} .
$$

Визначене за формулою (6) зменшення кінетичної енергії рідини на кожному наступному шарі при змиканні порожнини також представлені у таблиці. Як видно, величина $\Delta E$ на два порядки менша за загальну кількість теплоти, що виділилась внаслідок фазових перетворень $Q$, тобто в'язкими ефектами можна у цій моделі знехтувати.

У рамках використаної моделі руху границі кавітаційної порожнини зміна радіусів в діапазоні $R_{\max }=\left(2,5 \cdot 10^{-5} \div 2,0 \cdot 10^{-4}\right)$ м не впливає на стаціонарний розподіл температури в області рідини навколо одної пульсуючої порожнини.

Представлені у Таблиці 1 значення кумулятивного теплового ефекту $Q$ дозволяють оцінити також густину загального теплового потоку на перерізі капіляра. Вираз (2) можна переписати у вигляді 


$$
j_{q}=\frac{Q}{\Delta t \cdot A_{\perp}} \cdot N,
$$

де $\Delta t=4 \cdot(1 / v)-$ час формування кавітаційного конгломерату і перетину ним перерізу капіляра, знайдений у роботі. На частоті порядку 20 кГц, цей час становить, наприклад, $2 \cdot 10^{-4}$ с. Для визначення площі перерізу каналу капіляра $A_{\perp}$ використовувалось значення діаметру 0,7 мм, для якого були експериментальні дані, представлені на Рисунку 3. Кількість порожнин діаметром 0,1 мм, що складають кавітаційний конгломерат, була не меншою, ніж 10. Отримане значення для густини теплового потоку було не менш, ніж $1,5 \cdot 10^{4} \mathrm{BT} / \mathrm{m}^{2}$.

Окремою задачею було узгодити відносно малий розігрів рідини в капілярі $(\Delta T=2,1$ град) 3 достатньо високою густиною потоку тепла. Для цього враховувалось, що спрямований рух кавітаційних порожнин до каналу капіляра спричиняє формування гідродинамічного потоку рідини в капілярі.

\section{V. ОБГОВОРЕННЯ I ВИСНОВКИ}

Пропонуючи спрощену концептуальну модель кавітаційного охолодження в локальному околі вхідного перерізу капіляра, зануреного в рідину, піддану керованій дії ультразвукових коливань, ми ставили наступні основні цілі. Перша 3 них полягала в доведенні можливості інтерпретувати зростання кавітаційних пустот 3 допомогою фізично-обгрунтованої, на наш погляд, концепції пульсаційної моделі локального фазового переходу, який реалізується в масштабах декількох мікрон при наявності капіляра. Інша мета полягала в розробці елементарного розрахункового алгоритму для запропонованої моделі, набір вхідних параметрів якого дозволяв би оцінити апріорі холодильний ефект, який досягається використанням як одного, так i, можливо, багатьох капілярів, утворюючих охолоджувану "панель". Наведені в роботі результати не виключають такої можливості і узгоджені 3 попередніми дослідними даними, одержаними в дистильованій воді.

Необхідно відзначити важливу особливість запропонованої нами простої моделі кавітаційного охолодження, спричиненого випарюванням рідини всередину зростаючих бульбашок насиченої пари. Вона полягає у можливості прямого впливу на температурний ефект охолодження, який досягається шляхом вибору сукупності теплофізичних рівноважних характеристик рідини, що кавітує. До них, поряд з вже використаними в (1)-(3) величинами питомоі теплоти випаровування при поточній температурі зовнішньої границі зростаючої порожнини $r(\bar{T})$, Дж/кг і коефіцієнтом молекулярної самодифузії $D$, м² доцільно добавити такі фундаментальні характеристики і коефіцієнти переносу суцільного середовища, як ii середня густина $\rho>\rho_{\text {нас }}(\bar{T})$, теплопровідність $\lambda$, Вт/(м·К) і динамічну в'язкість $\eta$, Па·с. Оскільки суть ланцюжка рівнянь моделі (1-3) полягає в представленні відібраної кількості теплоти $\Delta q$ через відповідну кількість випареної рідини $\Delta m$, яке описується 3 допомогою узагальненого на опис локально-двофазних станів закону Фіка для самодифузії, нам потрібно оцінити, перш за все, можливі шляхи збільшення $\Delta m$ при заданому значенні $r(\bar{T})$. Як витікає з (3), це збільшення (тобто інтенсифікація випаровування всередині пустот) досягається 3 допомогою вибору максимального значення $D$. Фізична суть цього коефіцієнту в запропонованій моделі співпадає 3 роллю коефіцієнта температуропровідності. Тобто він вбачається подібним такому 3 теорії переносу для розріджених газів (де і справедливий оригінальний закон Фіка):

$$
D=\lambda /\left(\rho C_{P}\right) .
$$

Відзначимо, однак, що аналогічна інтерпретація самодифузії $D$ в якості кінематичної в'язкості:

$$
D=\eta / \rho
$$

$\epsilon$ певною суперечністю між бажаними трендами збільшення $\lambda$ i зменшення $C_{p}$ в (8), оскільки при тій самій густині $\rho$ це приводить до небажаного збільшення динамічної в'язкості $\eta$, згідно з (9).

Вирішення цієї суперечності між одночасними трендами збільшення $\lambda$ i $\eta$, яке пропонується нами, полягає в наступному. Оскільки припущення про оборотність рівноважного фазового переходу в локально-кавітуючій нестаціонарній рідині є досить грубим, замінимо його передбаченням типу використаного при "виведенні" експериментально знайденого закону Джоуля-Ленца для теплового ефекту електричного струму. Припустимо, що весь тепловий потік $j_{q}$, який відводиться 3 областей $\boldsymbol{I}$ і $\boldsymbol{I I}$ цілком (тобто оборотно) повертається до них за рахунок механізму теплопровідності і від'ємної різниці середніх температур, що виникає: $\Delta T=\left(T_{I, I I}-T_{I I I}\right), \mathrm{K}:$

$$
j_{q}=r(\bar{T}) D \frac{\Delta \rho}{\Delta r} N=\lambda \frac{\Delta T}{\Delta r} .
$$

Використовуючи (8) i виражаючи стаціонарне значення $\Delta T$ у вигляді:

$$
\Delta T=\frac{r(\bar{T}) \Delta \rho N(\bar{R}, v)}{C_{P}(\bar{T}) \rho},
$$

можна дійти до досить неочікуваного, на перший погляд, висновку про те, що обидва основних коефіцієнти переносу $\lambda$ і $\eta$ (тобто їх одночасне збільшення або зменшення) не впливає суттєво на бажану тенденцію збільшення різниці температур $\Delta T$ (тобто ефекту локального охолодження). Вона дося-гається при заданих механічних характеристиках кавітаційного процесу: $\Delta \rho \cdot N(\bar{R}, v) / \rho$ за раху-нок збільшення відношення двох теплових характеристик будьякої рідини: $r(\bar{T}) / C_{P}(\bar{T})$. Збільшення чисельника, 
тобто питомої теплоти пароутворення $r(\bar{T})$ вимагає, як відомо, зни-ження температури фазового переходу. Зменшення ізобарної однофазної теплоємності $C_{P}(\bar{T}, \rho)$, яка стоїть в знаменнику обговорю-ваного відношення, не так прямо пов'язане в більшості рідин із зміною температури і досить чутливе до зміни густини. Задача оптимізації локального холодильного ефекту кавітації, спричиненого ультразвуком, виглядає, в цьому контексті, досить перспективною для практики і ми сподіваємось розглянути ії детальніше в наступних публікаціях.

Обговорюючи можливі конструктивні рішення холодильних та теплотранс-портувальних пристроїв, звернемо увагу на те, що в експериментах [12] зона збудження кавітаціі знаходиться на віддаленні від випромінювача (порядку 10-15 мм), тобто практично є термостатованою навколишньою рідиною. Якщо звернутись до перших досліджень звукокапілярного ефекту [17], переріз капіляра був розташований на висоті $(50 \div 150)$ мкм, і контакт 3 рідиною зменшувався суттєво. У такому експерименті кавітаційні порожнини розпочинали фазу росту на поверхні випромінювача. Отже, він може, у принципі, відігравати роль холодоз'ймного елемента. Крім того, практично не існує обмежень для викори-стання інших рідин, ніж дистильована вода. Так, відомо, що кавітація збуджується і досліджу-ється в умовах кріогенних температур [18,19]. Отже, з нашої точки зору, існують підстави очікувати в подальшому розумних конструкт-тивних інженерних рішень, в основі яких може лежати керований звукокапілярний метод транспортування тепла.

\section{ЛIТЕРАТУРА}

1. Ceperley, P.H. 1985. Gain and efficiency of a short traveling wave heat engine. Journ.Acoust. Soc.Amer, 77 (3), 1239. doi:10.1121/1.421299

2. Swift, G.W. 1988. Thermoacoustic engines. Journ.Acoust.Soc.Amer., $\quad 84$ (4), 1145-1180 doi:10.1121/1.396617

3. Garrett S.l., Hofler T.J. 1992. Thermoacoustic refrigeration. ASHRAE Journ. 34 (12), 28-36.

4. Wilen, L.A. 1998. Measurements of thermoacoustic functions for single pores. Journ. Acoust.Soc.Amer., 103(3), 1406

doi:10.1121/1.421299
5. Petculescu,G., Wilen, L.A. 1999. Thermoacoustics in a single pore with an applied temperature gradient. Journ.Acoust.Soc.Amer. 106(102) 688-694. doi:10.1121/1.427086

6. Backhaus,S., Swift,G.W. Patent US №6032464, от 07.03.2000

7. Backhaus, S, Swift. G.W 2000. A thermoacoustic-Stirling heat engine: Detailed study. Journ.Acoust.Soc.Amer., $107 \quad$ (6), $\quad 3148$ doi:10.1121/1.429343

8. Gusev, V. 2001. Thermal wave harmonics generation in the hydrodynamical heat transport in thermoacoustics Journ.Acoust.Soc.Amer.-.109(1), 8490. doi:10.1121/1.1332383

9. Petculescu G., Wilen L.A. 2001. High ampli-tude thermoacoustic effect in a single pore Journ. Acoust.Soc.Amer. 109(3) 942 doi:10.1121/1.1348008

10. Миронов М.А., Пятаков П.А. Термоакустический холодильник Патент РФ 2435113, опубл 27.11.2011.

11. Розин Ю.П., Розина Е.Ю. О направленном смещении кавитационных полостей в канал капилляра// Вісник ОДУ, 2000.- Т.5, вип.3.- С.3238.

12. Розіна О.Ю., Тіструга О.М. Експериментальне дослідження теплових закономірностей в звукокапілярному ефекті// Вісник ОДУ.2002.- Т.6, вип.3.- С.170-176.

13. Акуличев В.А., Алексеев В.Н., Буланов В.А. Периодические фазовые превращения в жидкостях.-М.: Наука, 1986.- 280 с.

14. Долинский А.А. Тепломассообмен и гидродинамика в парожидкостных дисперсных средах. // А.А. Долинский, Г.К. Иваницкий. Киев.: Наукова думка - 2008 - 382 стр.

15. Флинн Г. Физика акустической кавитации в жидкостях// Физическая акустика / Под ред. Мэзона У.: Пер.с англ.- М.:Мир, 1967.- с.7-138.

16. Сивухин Д.В. Термодинамика и молекулярная физика. М.: Наука, - 1975. -550 с.

17. Розин Ю.П., Тихонова В.С, Костючек М.Н. Об аномально больших постоянных давления в непосредственной близости от излучателя// Укр.физ.журн.-1975.-Т.20, №2.- С.214-220.

18. Акуличев В.А. Кавитация в криогенных и кипящих жидкостях, М.: Наука, 1978 г, 280 стр.

19. Волков Г.А., Груздков А.А., Петров Ю.В. Кавитационная прочность криогенных жидкостей, критерий инкубационного времени ЖТФ, 2009, т.79, вып.11. стр.147-149. 
O.Yu. Rozina, V.B.Rogankov

Odessa national academy of food technologies, 112 Kanatnaya str., Odessa, 65039, Ukraine

\title{
GENERATION OF HEAT FLUX NEAR THE CAPILLARY IMMERSED INTO THE CAVITATING LIQUID DUE TO THE EXTERNAL ACOUSTICAL FIELD
}

\begin{abstract}
We propose the simple model of the heat flux generation throw the open end of the capillary cannel submersed into liquid, where an ultrasonic field is formed. This model is based on the previous experimental research of the sonic-capillary effect. The peculiarities of them are: the excitation of cavitations strongly under the capillary cannel; the translation motion of cavities to the capillary cannel, recorded by mean of the moving image camera with the velocity of about 160000 frames per second; the local heating of liquid in capillary and temperature distribution in the capillary cannel; the gradient of temperature directed according the translation motion of the cavities. The principal distinction of our model is that the cavitation process is connected with a periodical phase transitions. Due to the directional motion of cavities to the capillary cannel, all thermodynamic processes, connected with extension of cavities and which need some quality of heat are located under the capillary cannel; the decreasing of cavities and the return of heat are located in the capillary cannel. Thus, the result heat flux forms throw the open capillary section. The proposed model is realized as a software and calculated in wide ranges of temperature, diameters of cavities, frequencies of ultrasonic. The density of heat flux was calculated for the conditions of based experiments.
\end{abstract}

Key words : Heat flux; Capillary; Ultrasonic cavitation; Phase transition

\section{REFERENCES}

1. Ceperley, P.H. 1985. Gain and efficiency of a short traveling wave heat engine. Journ.Acoust. Soc.Amer, 77 (3), 1239. doi: 10.1121/1.421299

2. Swift, G.W. 1988. Thermoacoustic engines. Journ.Acoust.Soc.Amer., $\quad 84$ (4), 1145-1180 doi: 10.1121/1.396617

3. Garrett S.l., Hofler T.J. 1992. Thermoacoustic refrigeration. ASHRAE Journ. 34 (12), 28-36.

4. Wilen, L.A. 1998. Measurements of thermoacoustic functions for single pores. Journ. Acoust.Soc.Amer., 103(3), 1406

doi:10.1121/1.421299

5. Petculescu,G., Wilen, L.A. 1999. Thermoacoustics in a single pore with an applied temperature gradient. Journ.Acoust.Soc.Amer. 106(102) 688-694. doi: 10.1121/1.427086

6. Backhaus,S., Swift,G.W. Patent US №6032464, от 07.03.2000

7. Backhaus, S, Swift. G.W 2000. A thermoacoustic-Stirling heat engine: Detailed study. Journ. Acoust. Soc. Amer., 107 (6), 3148

doi: $10.1121 / 1.429343$

8. Gusev, V. 2001. Thermal wave harmonics generation in the hydrodynamical heat transport in thermoacoustics Journ. Acoust. Soc. Amer, 109(1), 84-90. doi: 10.1121/1.1332383

9. Petculescu, G., Wilen, L.A. 2001. High amplitude thermoacoustic effect in a single pore Journ.
Acoust.Soc.Amer., 109(3), 942 doi:10.1121/1.1348008 10. Mironov, M.A. Pyatakov, P.A. Thermoacoustic refrigeration. Patent RF 2435113, pub 27.11.2011

11. Rosin, Yu.P., Rozina, E.Yu. 2000. Translation motion of the cavities inti the capillary cannel. Visnik $O D U, 5(3), 32-38$.

12. Rozina, E.Yu., Tistruga, O.M. 2002. Experimentally research of the heat phenomena in the sonic-capillary effect. Visnik $O D U, 6(3), 170-176$.

13. Akulichev, V.A., Alekseev, V.N., Bulanov, V.A. Periodical phase transitions in liquids.- M.: Nauka, 1986.- 280 p.

14. Dolinskiy, A.A., Ivanitzkiy, G.K. 2008. Heatmass transfers and hydrodynamics in vapor-liquid dispersed systems. Kiev: Nauk. dumka, 2008, 382 p 15. Physical acoustics. Principles and methods. Ed. by W.P.Mason. 1964, V.1 (B) Acad.press, NewYork, London, $362 \mathrm{p}$.

16. Sivuchin D.V. Thermodynamics and molecular physics. M.: Nauka, 1975.- 550 p.

17. Rosin Yu.P., Tichonova V.S., Kostyuchek M.N. Anomaly great level pressure near the ultrasonic transducer. Ukr.Phys.Journ, 1975, 20(2), p.214-220.

18. Akulichev V.A., Cavitation in cryogenic and boiled liquids, M.: Nauka, 1978.- $280 \mathrm{p}$

19. Volkov G.A., Gruzdkov A.A., Petrov Yu.V. 2009. Cavitations stability of cryogenic liquids. Journ. Tech. Phys., 79(11), 147-149.

Отримана в редакції 05.02.2015, прийнята до друку 23.04.2015 